\title{
Resistance Plasmids of Aeromonads
}

\author{
By R. W. HEDGES, ${ }^{*}$ P. SMITH ${ }^{2}$ AND G. BRAZIL ${ }^{2} \dagger$ \\ ${ }^{1}$ Plant Genetic Systems, Plateaustraat 22, B-9000 Gent, Belgium \\ ${ }^{2}$ Microbiology Department, University College Galway, Ireland
}

(Received 30 November 1984; revised 15 February 1985)

\begin{abstract}
The resistance plasmids of isolates of Aeromonas hydrophila and $A$. salmonicida from Japan, France, the UK and Ireland have been characterized. Three classes of plasmids transmissible to Escherichia coli were found: plasmids of incompatibility group C, plasmids of incompatibility group $\mathrm{U}$, and plasmids incapable of stable inheritance in $E$. coli, not belonging to any defined incompatibility group.
\end{abstract}

\section{INTRODUCTION}

Aeromonads constitute a well defined genus usually assigned to the family Vibrionaceae, although recent studies have suggested that they may be more closely related to the Enterobacteriaceae and should, perhaps, be considered as a distinct family (Baumann \& Schubert, 1984).

Aoki et al. (1971) demonstrated resistance plasmids (' $R$ factors' or R plasmids) in Aeromonas liquefaciens ( $A$. hydrophila) and transferred them to Escherichia coli. Hedges \& Datta (1971) showed that these plasmids were of two sorts, half belonging to incompatibility group A, now regarded as part of group C (Sirgel et al., 1981), whilst the others are now regarded as the prototypes of group U (Tschäpe et al., 1981). Mizon et al. (1978) studied $\mathrm{R}$ factors in $A$. hydrophila isolates from a hospital in Paris. Half were of group $\mathrm{C}$ whilst the others were not assigned to any group. A collection of $A$. salmonicida strains from a fish hatchery on the west coast of Ireland was available to us. We decided to characterize the R plasmids from these three sets of aeromonads isolated from very different ecosystems in geographically well separated localities.

\section{METHODS}

Bacteria. Aeromonas spp. are listed in Table 1.

Techniques for study of plasmids. Escherichia coli $\mathrm{K} 12$ strains $\mathrm{J} 53$ and $\mathrm{J} 62$ (and mutants resistant to nalidixic acid or rifampicin) were used as plasmid recipients. Techniques for plasmid transfer and the determination of incompatibility specificity were as described by Datta et al. (1971) and Coetzee et al. (1972).

Plasmid isolation and molecular weight determination. The techniques of Birnboim \& Doly (1979) and Datta et al. (1979) were used.

\section{RESULTS}

\section{Plasmids transferred from Aeromonas hydrophila}

The $\mathbf{R}$ plasmids transmissible to $E$. coli fell into three classes: plasmids of incompatibility group $\mathrm{U}$ were detected in all three collections, plasmids of group $\mathrm{C}$ were transferred from Japanese and French isolates, and both French and Irish aeromonads carried plasmids which were notably unstable in $E$. coli. Representatives of all plasmids transferred are presented in Table 1.

† Present address: Genetics Department, Trinity College, Dublin, Ireland. 


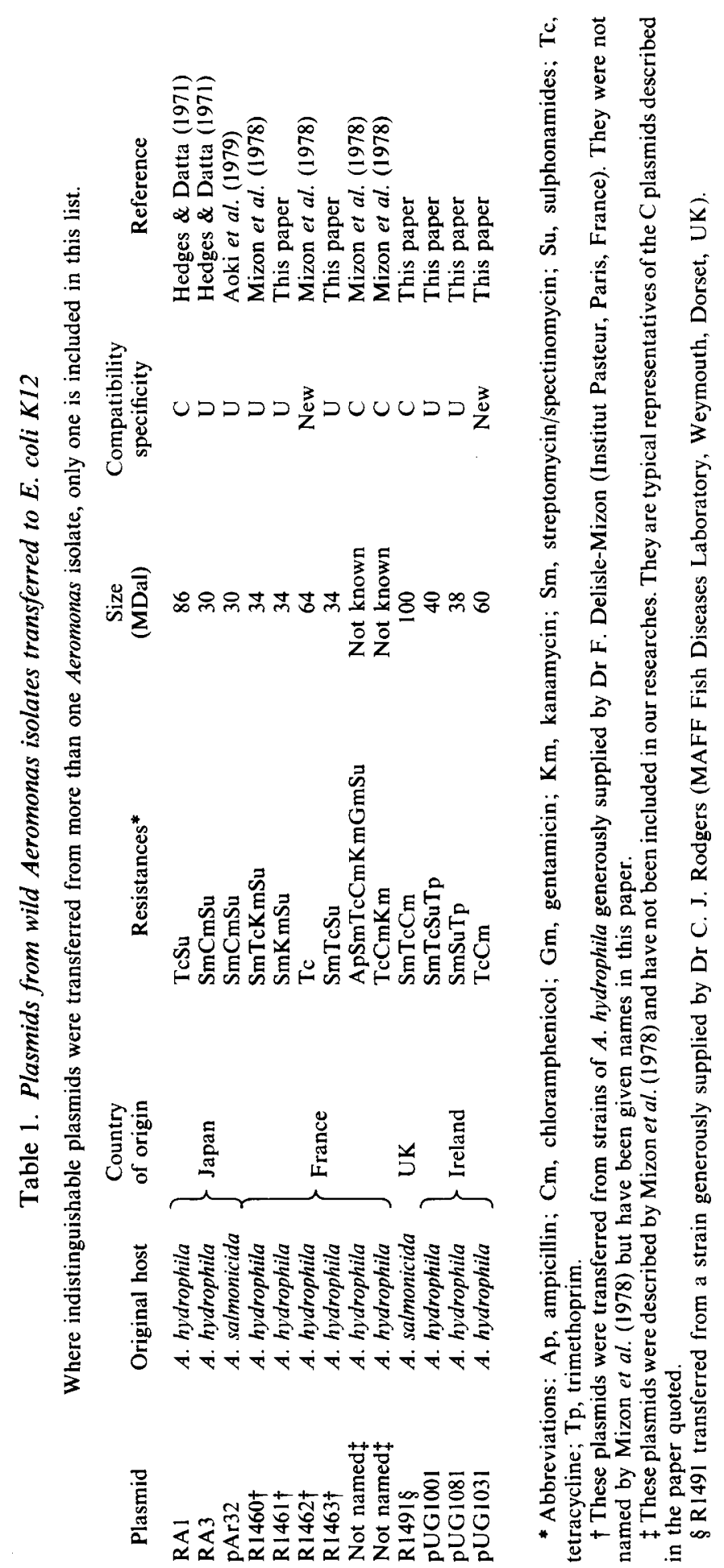


Plasmids of group $U$. These plasmids were the only incompatibility group detected in isolates from all three collections. The three sets differed in their characteristic resistance patterns: the $\mathrm{Sm}$ and Su resistances were invariable but the other resistances $(\mathrm{Cm}$, in the Japanese, $\mathrm{Km}$ and $\mathrm{Tc}$ in the French, Tc and $\mathrm{Tp}$ amongst the Irish plasmids) were variable within and between populations (Table 1). The former resistances were stable in E. coli, and (apart from plasmid-free segregants) no $\mathrm{Sm}^{\mathrm{s}}$ or $\mathrm{Su}^{\mathrm{s}}$ variants were ever observed, whilst the other resistances were more readily lost (very roughly one sensitive segregant per thousand cells) during growth on drug free media.

These results suggest that, like plasmids of group W (Gorai et al., 1979) and group $P$ (Villarroel $e t$ al., 1983), U plasmids have a relatively uniform structure into which transposons are incorporated and spread as the markers they carry are selected. We have no direct evidence of transposability of the $\mathrm{Km}$ or Tc markers but the Tp determinant of, for example, pUG1001 readily transposed into the $E$. coli chromosome and appears to resemble closely the well characterized Tn7 (Richards \& Nugent, 1979). The sizes of the plasmids fit well with this interpretation (Table 1). The Japanese and French plasmids are all in the 30-34 MDal region and though the Irish plasmids are larger, the presence of a Tn7-like transposon accounts for the increase.

Plasmids of this group have a wide host range and are capable of functioning in many species. It is clear that they are widely distributed in aeromonads, yet the only report of such plasmids in bacteria other than this genus is that of Tschäpe et al. (1981), who found several U plasmids in hospital isolates of enteric bacteria from East Germany and Czechoslovakia. The present evidence suggests that the group is characteristic of aeromonads but does occasionally transfer to and establish itself in other genera. Plasmids may acquire some of the transposons present in the gene pools of these bacteria and subsequently ferry these back to the aeromonads. Thus, it may be no coincidence that one of the plasmids described by Tschäpe et al. (1981) appears to be similar to pUG1001 (a carrier of the Tn7-like transposon) in molecular weight and resistance pattern. The EcoRI restriction nuclease digests were also very similar (G. Brazil, unpublished).

Bradley (1980) showed that transmissible plasmids of enteric bacteria could be divided into two classes, those with flexible pili and those with rigid ones. Members of the latter group (to which U plasmids belong) seem to be opportunistic genetic elements characterized by broad host ranges and constitutive production of sex pili. The majority of these confer sensitivity to the pilus phages of the PRD1 class (Bradley et al., 1982). These phages should be able to cause sudden declines in plasmid-carrying bacterial populations. U plasmids are untypical in not conferring sensitivity to these phages. After a hospital epidemic involving such a phage, there will be an empty ecological niche for an opportunistic plasmid conferring antibiotic resistances, and U plasmids in hospital aeromonads (Mizon et al., 1978) may transfer to enteric bacteria and multiply in these hosts.

The ecology of $U$ plasmids may then be characterized as primarily being typical plasmids of aeromonads with opportunistic spread into other genera when the normal plasmid sets of those bacteria are depleted. The large majority of the U plasmids entering other genera are probably eventually lost (out-competed) but a few, retransferring to aeromonads, may introduce genetic determinants, thus adding to the gene pool of the genus.

Plasmids of group C. R plasmids of this group were found in A. hydrophila isolates from both Japan and France. These plasmids have a notably wide natural host range. In view of the possibility that Aeromonas may be related to the genus Vibrio, it may be worth noting that $\mathrm{C}$ plasmids dominate the $\mathrm{R}$ plasmid set of $V$. cholerae (Hedges et al., 1977). The plasmids from marine vibrios described by Arai \& Aoki (1977) are also members of group C (N. Datta, personal communication). It is, however, notable that another fish pathogen, Edwardsiella tarda carries C plasmids (Aoki et al., 1977) and these plasmids may have acquired a role amongst bacteria of diverse lineages in this ecological niche.

Plasmids unstable in E. coli. R plasmids which appear to be stable in the original $A$. hydrophila host but which are highly unstable after transfer to $E$. coli were observed in the French and Irish populations. Representatives (R1462 and pUG220) were transferred from E. coli K12 with plasmids representing the known incompatibility groups. In no case did their entry lead to the 
elimination of the resident plasmid. Thus, neither plasmid is a member of any defined. incompatibility group. As both were extremely unstable it was not possible to test their mutual compatibility. The two plasmids are similar in size and both are decidedly more stable during growth at $30^{\circ} \mathrm{C}$ than at $37^{\circ} \mathrm{C}$, (results not shown), and these similarities may indicate relatedness.

Attempts to detect plasmids capable of transfer between strains of $A$. hydrophila (the recipients marked by chromosomal antibiotic resistance mutations), but not into $E$. coli, all failed.

\section{Plasmids transferred from A. salmonicida}

A. salmonicida constitutes a well defined species by morphological, taxonomic and molecular criteria (Sakazaki \& Balows, 1981; Popoff, 1984) and it has been suggested that it should be elevated to form a separate genus. Nevertheless, the plasmid sets of $A$. salmonicida and $A$. hydrophila are very similar, including plasmids of groups $\mathrm{C}$ and $\mathrm{U}$ as well as plasmids unstable in E. coli (Table 1).

\section{DISCUSSION}

It is a general ecological principle that two biological species with exactly similar ecological niches cannot co-exist stably (Gause, 1934). The logic should hold true for plasmid groups, yet it seems that most bacterial species support several distinct plasmid groups; Aeromonas supports at least three. One possible explanation is that the populations may not have reached equilibrium. Chemotherapy was started only about 40 years ago and many new drugs have been brought to bear on bacterial populations. The present day plasmid distribution may be a transitional phase: yet, what is known of bacteria in the prechemotherapeutic period indicates a diversity of plasmids comparable with the present day (Datta \& Hughes, 1983).

An alternative view is that the different plasmid groups play different ecological roles. The plasmids noted as being unstable in $E$. coli seem to be particularly well adapted to existence in aeromonads and may well be ecologically limited to that genus. Thus, they can evolve towards a more complete integration in to the Aeromonas genome. On the other hand, $\mathrm{C}$ plasmids occur in a very wide range of bacterial families. This type of plasmid cannot adapt so precisely to any one host species but can exploit a huge range of host species (and hence a wide range of physical environments). The role of $U$ plasmids has already been discussed. It may be significant that both $\mathrm{C}$ and $\mathrm{U}$ plasmids determine pili capable of conferring phage sensitivity (Sirgel et al., 1981; Bradley et al., 1981). Such phages may play significant roles in the ecology of these plasmids.

We are grateful to Dr T. Aoki (Miyazaki University, Japan), Dr T. Arai (Keio University, Tokyo, Japan), Dr F. Delisle-Mizon (Institut Pasteur, Paris, France), Dr C. J. Rodgers (MAFF Fish Diseases Laboratory, Weymouth, UK) and Dr J. V. Lee (PHLS, Maidstone, UK) for Aeromonas isolates. Dr H. Richards (now at Searle R \& D, High Wycombe, UK) determined the plasmid molecular weights and Professor N. Datta (Hammersmith Hospital, London, UK) provided inspiration. We thank Karin Tenning for preparing so many drafts of this script.

\section{REFERENCES}

Aoki, T., Egusa, S., Ogata, Y. \& Watanabe, T. (1971). Detection of resistance factors in fish pathogen Aeromonas liquefaciens. Journal of General Microbiology 65, 343-349.

Aoki, T., AraI, T. \& Egusa, S. (1977). Detection of R plasmids in naturally occurring fish-pathogenic bacteria, Edwardsiella tarda. Microbiology and Immunology 21, 77-83.

Aoki, T., Kitao, T., ANDo, T. \& AraI, T. (1979). Incompatibility grouping of $\mathbf{R}$ plasmids detected in fish pathogenic bacteria Aeromonas salmonicida. In Microbial Drug Resistance, vol. II, pp. 219-222. Edited by S. Mitsuhashi. Baltimore, Md.: University Park Press.
ARAI, T. \& AOKI, T. (1977). New R plasmid-mediated restriction-modification system of DNA conferred by group E R plasmids. Journal of Bacteriology 130, 529-531.

Baumann, P. \& Schubert, R. H. W. (1984). Vibrionaceae. In Bergey's Manual of Systematic Bacteriology, vol. 1, pp. 516 517. Edited by N. R. Krieg \& J. G. Holt. Baltimore: Williams \& Wilkins.

Birnboim, H. C. \& Doly, J. (1979). A rapid alkaline extraction procedure for screening recombinant plasmid DNA. Nucleic Acids Research 7, 15131523.

Bradley, D. E. (1980). Morphological and serological relationships of conjugative pili. Plasmid 4, 155-169. 
Bradley, D. E., Coetzee, J. N., Bothma, T. \& Hedges, R. W. (1981). Phage X: a plasmiddependent, broad host range, filamentous bacterial virus. Journal of General Microbiology 126, 389-396.

Bradley, D. E., Aoki, T., Kitao, T., Arai, T. \& TSCHÄPE, H. (1982). Specification of characteristics for the classification of plasmids in incompatibility group U. Plasmid 8, 89-93.

Coetzee, J. N., Datta, N. \& Hedges, R. W. (1972). R factors from Proteus rettgeri. Journal of General Microbiology 72, 543-552.

Datta, N. \& Hughes, V. M. (1983). Plasmids of the same Inc groups in enterobacteria before and after the medical use of antibiotics. Nature, London 306, 616-617.

Datta, N., Hedges, R. W., Shaw, E. J., Sykes, R. B. \& Richmond, M. H. (1971). Properties of an R factor from Pseudomonas aeruginosa. Journal of Bacteriology 108, 1244-1249.

DatTa, N., Hughes, V. M., Nugent, M. E. \& Richards, H. (1979). Plasmids and transposons and their stability and mutability in bacteria isolated during an outbreak of hospital infection. Plasmid 2, 182-196.

Gause, G. F. (1934). The Struggle for Existence (Reprinted by Hafner Press New York, 1964).

Gorai, A. P., Hefroron, F., Falkow, S., Hedges, R. W. \& DATTA, N. (1979). Electron microscope heteroduplex studies on sequence relationships among plasmids of the $\mathrm{W}$ incompatibility group. Plasmid 2, 485-492.

Hedges, R. W. \& Datta, N. (1971). fi ${ }^{-}$R factors giving chloramphenicol resistance. Nature, London 234, 220-221.

Hedges, R. W., Vialard, J. L., Pearson, N. J. \& O'GraDY, F. (1977). R plasmids from Asian strains of Vibrio cholerae. Antimicrobial Agents and Chemotherapy 11, 585-588.

Mizon, F. M., Gerbaud, G. R., Leclere, H. \& Chabbert, Y. A. (1978). Présence de plasmids de résistance appartenant un groupe d'incompatibilité C chez Aeromonas hydrophila isolé d'eaux résiduaires. Annales de microbiologie 129B, 19-26.

Popoff, M. (1984). Aeromonas. In Bergey's Manual of Systematic Bacteriology, vol. 1, pp. 545-548. Edited by N. R. Krieg \& J. G. Holt. Baltimore: Williams \& Wilkins.

RichaRDS, H. \& Nugent, M. E. (1979). The incidence and spread of transposon 7. In Plasmids of Medical, Environmental and Commercial Importance, pp. 195198. Edited by K. N. Timmis \& A. Pühler. Amsterdam: Elsevier-North Holland Biomedical Press.

Sakazaki, R. \& Balows, A. (1984). The genus Aeromonas. In The Prokaryotes, pp. 1288-1301. Edited by M. P. Starr, H. Stolp, H. Trüper, A. Balows \& H. G. Schlegel. Berlin: Springer Verlag. Sirgel, F. A., Coetzee, J. N., Hedges, R. W. \& LeCatsas, G. (1981). Phage $\mathrm{C} 1$ : an IncC group plasmid-specific phage. Journal of General Microbiology 122, 155-160.

TSCHÄPE, H., TIETZE, E. \& KOCH, C. (1981). Characterization of conjugative $\mathrm{R}$ plasmids belonging to the new incompatibility group IncU. Journal of General Microbiology 127, 155-160.

Villarroel, R., Hedges, R. W., Maenhaut, R., LeEmans, J., ENGleR, G., VAN Montagu \& SChell, J. (1983). Heteroduplex analysis of $\mathbf{P}$ plasmid evolution: the role of insertion and deletion of transposable elements. Molecular and General Genetics 189, 390-399. 